\title{
Fine Particulate Matter and Ozone Pollution in the 18 Cities of the Sichuan Basin in Southwestern China: Model Performance and Characteristics
}

\author{
Xue Qiao ${ }^{1,2,3}$, Hao Guo ${ }^{3}$, Pengfei Wang ${ }^{3}$, Ya Tang ${ }^{4}$, Qi Ying ${ }^{5}$, Xing Zhao ${ }^{6}$, Wenye Deng ${ }^{7}$, \\ Hongliang Zhang ${ }^{3,8^{*}}$ \\ ${ }^{1}$ Institute of New Energy and Low-Carbon Technology and Healthy Food Evaluation Research Center, Sichuan \\ University, Chengdu 610065, China \\ ${ }^{2}$ State Key Laboratory of Hydraulics and Mountain River Engineering, Sichuan University, Chengdu 610065, China \\ ${ }^{3}$ Department of Civil and Environmental Engineering, Louisiana State University, Baton Rouge, LA 70803, USA \\ ${ }^{4}$ College of Architecture and Environment and Healthy Food Evaluation Research Center, Sichuan University, Chengdu \\ 610065, China \\ ${ }^{5}$ Zachry Department of Civil Engineering, Texas A\&M University, College Station, TX 77843, USA \\ ${ }^{6}$ Department of Epidemiology and Biostatistics, West China School of Public Health, Sichuan University, Chengdu \\ 610041, China \\ ${ }^{7}$ Xinjiang Academy of Environmental Protection Science, Urumqi 830011, China \\ ${ }^{8}$ Department of Environmental Science and Engineering, Fudan University, Shanghai 200438, China
}

\begin{abstract}
The Sichuan Basin (SCB) is located in southwestern China and has a total population of 108.1 million across 18 cities, including the 2 largest in western China (Chengdu and Chongqing). As most air quality monitoring stations are located in urban areas, we simulated the $\mathrm{PM}_{2.5}$ (i.e., particulate matter with an aerodynamic diameter $\left.<2.5 \mu \mathrm{m}\right)$ and ozone $\left(\mathrm{O}_{3}\right)$ in the entire SCB during winter (December 2014-February 2015) and summer (June-August 2015) by using the Weather Research and Forecasting (WRF) and the Community Multi-scale Air Quality (CMAQ) models. The simulated concentrations of 24-h $\mathrm{PM}_{2.5}$ and its major components generally agree with observations during both seasons, but the simulated 1-h and 8-h $\mathrm{O}_{3}$ are acceptable only for summer. Increasing in severity from the rim of the SCB to its inner areas, the $\mathrm{PM}_{2.5}$, as well as its major components, exhibits hotspots near the central urban areas of Chongqing and Chengdu, with concentrations of $150-200 \mu \mathrm{g} \mathrm{m}^{-3}$ and $40-60 \mu \mathrm{g} \mathrm{m}^{-3}$ during winter and summer, respectively. The 1-h and 8-h $\mathrm{O}_{3}$ exhibit no hotspots in the urban centers of Chongqing and Chengdu but show elevated levels in some rural and suburban areas (55-70 ppb and 65-80 ppb, respectively), including those on the western and southwestern rim of the SCB, and downwind of the urban center of Chongqing. Despite the great spatial variations in the $\mathrm{PM}_{2.5}$ and $\mathrm{O}_{3}$ concentrations, the vast majority of the basin fails to meet the WHO guidelines for 24-h $\mathrm{PM}_{2.5}\left(25 \mu \mathrm{g} \mathrm{m}^{-3}\right)$ and $8-\mathrm{h} \mathrm{O}_{3}(\sim 47 \mathrm{ppb})$ on $>70 \%$ of the days during winter and $>40 \%$ of the days during summer, respectively. Based on the aforementioned spatial patterns of the $\mathrm{PM}_{2.5}$ and $\mathrm{O}_{3}$ concentrations, and the wind directions within the basin, strictly controlling emissions originating in the SCB may greatly reduce $\mathrm{PM}_{2.5}$ and $\mathrm{O}_{3}$ concentrations within the basin.
\end{abstract}

Keywords: Chengdu; Chongqing; Spatio-temporal variations; Air pollution.

\section{INTRODUCTION}

Air pollution is one of the most severe environmental problems in China. While haze is still a severe problem in China (Wang and Hao, 2012; Zhang et al., 2012a; Zhang et al., 2012b; Aunan et al., 2018), ozone $\left(\mathrm{O}_{3}\right)$ has become an

\footnotetext{
* Corresponding author.

Tel.: +1-225-578-0140

E-mail address: hlzhang@1su.edu
}

increasingly important pollutant in recent years (Verstraeten et al., 2015; Anger et al., 2016; Ma et al., 2016; Sun et al., 2016; Wang et al., 2017; Shen et al., 2019a), as a result of increased emissions of volatile organic compounds (VOCs) in the VOC-limited regions (Shen et al., 2019b), decreased nitrogen oxides $\left(\mathrm{NO}_{x}\right)$ in some VOC-limited regions ( $\mathrm{Li}$ et al., 2019), and slowed aerosol sink of hydroperoxy radicals that stimulates $\mathrm{O}_{3}$ production ( $\mathrm{Li}$ et al., 2019). Air pollution has caused significant adverse effects on human health. It was estimated that more than 1 million premature deaths each year in China were attributable to outdoor air pollution (Lelieveld et al., 2015). In order to mitigate air 
pollution, the Ministry of Environmental Protection of the People's Republic of China (MEP) has grouped the areas that are most affected by air pollution in the country into 3 regions and 10 city clusters (MEP, 2013; Fig. S1), including (1) Beijing-Tianjin-Hebei (BTH), (2) Yangtze River Delta (YRD), (3) Pearl River Delta (PRD), (4) central regions of Liaoning Province, (5) Shandong Province, (6) Wuhan and its peripheral localities, (7) Changsha, Zhuzhou, and Xiangtan in Hunan Province, (8) the Chengdu-Chongqing city cluster in the Sichuan Basin (SCB), (9) western coast of the Taiwan Strait, (10) central and northern regions of Shansi Province, (11) Guanzhong Plain in Shanxi Province, (12) parts of Gansu and Ningxia Province, and (13) Urumqi in Xinjiang Province. In total, these areas cover 1.32 million $\mathrm{km}^{2}$ and have a population of 675 million, accounting for $14 \%$ of China's land, $48 \%$ of the country's population, $71 \%$ of national gross domestic product (GDP), 52\% of national coal consumption, and $50 \%$ of the national emission of sulfur dioxide $\left(\mathrm{SO}_{2}\right), \mathrm{NO}_{x}$, particulate matter $(\mathrm{PM})$, and volatile organic compounds (VOCs) (MEP, 2013).

Among the 3 regions and 10 city clusters, the ChengduChongqing city cluster in the SCB has the largest area (0.22 million $\left.\mathrm{km}^{2}\right)$ and the second largest population (108.1 million) (MEP, 2013). Within the basin, there are 16 cities belonging to the Chengdu-Chongqing city cluster and the other 2 cities are located in the north of the SCB (Fig. 1). The information of area, population, GDP, and air pollutant concentrations in each city are provided in Table S1. Due to the basin landform and high anthropogenic emissions within the basin, air pollution is severe and the major air pollutants are $\mathrm{O}_{3}$ and $\mathrm{PM}_{2.5}$ (i.e., $\mathrm{PM}$ with an aerodynamic diameter $<2.5 \mu \mathrm{m}$ ) (Ning et al., 2018; Zhao et al., 2018a, b; Zhang et al., 2019). In 2015, annual $\mathrm{PM}_{2.5}$ concentrations measured in the 18 cities were in the range of 21-74 $\mathrm{g} \mathrm{m} \mathrm{m}^{-3}$ (Table S1), about 2-7 times of the World
Health Organization (WHO) guideline of $10 \mu \mathrm{g} \mathrm{m}^{-3}$ (WHO, 2006). Annual $90^{\text {th }}$ percentiles of $8-\mathrm{h} \mathrm{O}_{3}$ in the 18 cities were measured in the ranges of 32-86 ppb in 2015, with 5 cities having values over $70 \mathrm{ppb}$. According to the measurements at the national air quality stations (NAQs; Fig. 1), $\mathrm{PM}_{2.5}$ concentrations were highest in winter but lowest in summer, and non-attainment days due to $\mathrm{PM}_{2.5}$ pollution were more frequent in winter (Ning et al., 2018; Zhao et al., 2018b). In contrast, $\mathrm{O}_{3}$ was the major pollutant in summer (Ning et al., 2018; Zhao et al., 2018b). However, as almost all the NAQs are located in the urban and suburban areas, the characteristics of air pollution have not been investigated in detail for the entire basin, particularly for the vast rural areas.

Chemical transport models (CTMs) have been applied to study air pollution for China as a whole (Hu et al., 2016; Li et al., 2016; Zhu and Liao, 2016) and for several regions of China, such as the YRD (Liao et al., 2015), NCP (Wang et al., 2012), and PRD (Fan et al., 2014). In previous nationwide CTM simulations, model performance on the SCB region was evaluated only for Chengdu and Chongqing, as observations in most of the cities in the basin were not available before 2015. For example, Hu et al. (2016) applied the Community Multi-scale Air Quality (CMAQ) (Byun and Schere, 2006) and the Weather Research Forecasting (WRF) (University Corporation for Atmospheric Research (UCAR), 2017) modeling system to predict air pollutant concentrations for the whole of China. The results show that 1-h and 8-h $\mathrm{O}_{3}$ and 24-h $\mathrm{PM}_{2.5}$ from March to December 2013 were over-predicted but $\mathrm{PM}_{10}$ (i.e., PM with an aerodynamic diameter $<10 \mu \mathrm{m})$ was under-predicted in Chengdu and Chongqing. In addition to the limitations of atmospheric models and emission inventories, the biases in air pollutant predictions might be associated with the coarse horizontal resolution $(36 \mathrm{~km} \times 36 \mathrm{~km})(\mathrm{Hu}$ et al., 2016).

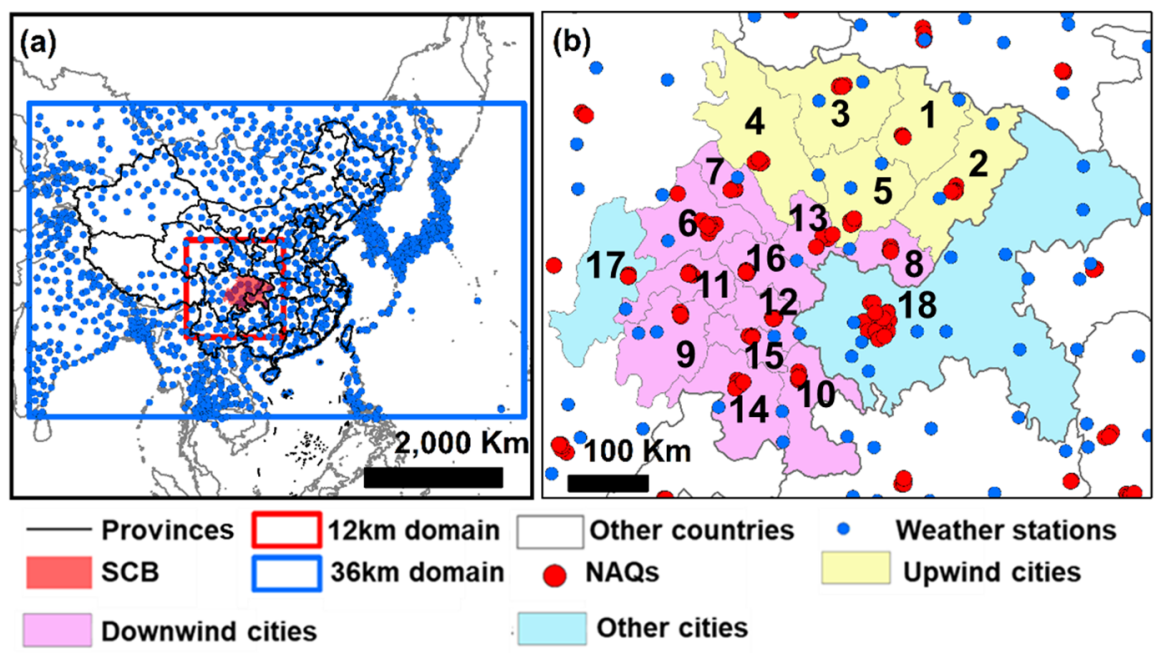

Fig. 1. (a) Locations of simulation domains and meteorological stations and (b) locations of the 18 cities in the SCB and national air quality stations (NAQs). Almost all the NAQs are located in the 18 SCB urban centers. The upwind and downwind regions are defined based on wind directions within the SCB, as shown in Figs. 5(a) and S4(a). Upwind cities: 1) Bazhong, 2) Dazhou, 3) Guangyuan, 4) Mianyang, and 5) Nanchong. Downwind cities: 6) Chengdu, 7) Deyang, 8) Guang'an, 9) Leshan, 10) Luzhou, 11) Meishan, 12) Neijiang, 13) Suining, 14) Yibin, 15) Zigong, and 16) Ziyang. Other cities: 17) Ya'an and 18) Chongqing. 
The SCB is located in the transition region from central China to the Qinghai-Tibetan Plateau (QTP) with great elevation changes; thus, the landform is complex and using coarse horizontal resolutions may not accurately predict wind speed (WS), wind direction (WD), and other meteorological parameters. Given the potential high risk from air pollution to human health, there is a need to use a higher horizontal resolution to systematically model the characteristics, sources, and health impacts of air pollution for the SCB.

In this study, a modified WRF/CMAQ modeling system was used to simulate $\mathrm{PM}_{2.5}$ and $\mathrm{O}_{3}$ in winter (December 2014-February 2015) and summer (June-August 2015) for the entire SCB. The model performance is evaluated, the spatio-temporal variations of the 2 pollutants and $\mathrm{PM}_{2.5}$ components are analyzed, the non-attainment conditions are determined, and air pollution is compared among the 18 SCB cities. This is the first study that comprehensively investigates the air quality status as well as variations of criteria air pollutants and $\mathrm{PM}_{2.5}$ components for all the SCB cities. This study provides the basis for our other studies on the source apportionment (Qiao et al., 2019), health effects, and control strategies of air pollutants in the SCB.

\section{METHODS AND MATERIALS}

\section{Model Description and Application}

The WRF/CMAQ modeling system was applied for the SCB using nested domains. The 36-km domain $(197 \times 129$ grid cells) covers all of China and surrounding countries in East Asia, while the $12-\mathrm{km}$ domain $(118 \times 118$ grid cells $)$ covers the entire SCB and its adjacent regions (Fig. 1). Meteorological inputs were generated using the WRF model version 3.9 with initial and boundary conditions (IC and BC) from the U.S. National Centers for Environmental Prediction (NCEP) Final (FNL) Operational Model Global Tropospheric Analyses dataset $\left(1^{\circ} \times 1^{\circ}\right.$ resolution; available at http://dss.ucar.edu/datazone/dsszone/ds083.2/). Detailed WRF model configurations are listed in Table S2. The CMAQ model version 5.0.1 was used to model air pollutant concentrations and modifications were made to improve the prediction of secondary inorganic and organic aerosols, including (1) providing more detailed treatment of isoprene oxidation chemistry SARPC-11 gas-phase photochemical mechanism (Ying et al., 2015); (2) allowing surface-controlled reactive uptake of dicarbonyls, isoprene epoxydiol (IEPOX), and methacrylic acid epoxide (Crippa et al., 2018) for secondary organic aerosol (SOA) formation (Li et al., 2015; Ying et al., 2015); (3) updating SOA yields based on vapor wall-loss correction (Zhang et al., 2014); and (4) improving nitrate and sulfate formation through heterogeneous reactions of $\mathrm{NO}_{2}$ and $\mathrm{SO}_{2}$ (Wang et al., 2014). More details of these modifications can be found in the cited references and the references therein. The model has been used in some studies for Asian countries ( $\mathrm{Hu}$ et al., 2016; Kota et al., 2018).

Other input files used to run the CMAQ model include the IC and $\mathrm{BC}$ of chemicals and the anthropogenic and natural emissions. The default CMAQ IC and BC profiles were used for the $36-\mathrm{km}$ simulation and the outputs of the $36-\mathrm{km}$ simulation were used to generate the chemical IC and $\mathrm{BC}$ files for the $12-\mathrm{km}$ simulations. Anthropogenic emissions files were generated based on the Emission Database for Global Atmospheric Research (EDGAR) version 4.3, which provided the datasets of carbon monoxide (CO), $\mathrm{NO}_{x}, \mathrm{SO}_{2}$, ammonia $\left(\mathrm{NH}_{3}\right), \mathrm{VOCs}, \mathrm{PM}_{2.5}, \mathrm{PM}_{10}$, elemental carbon (EC), and organic carbon (OC) (Crippa et al., 2018). As the EDGAR database provides only monthly total emissions of air pollutants, an in-house preprocessor was used to generate hourly emissions based on monthly, weekly, and temporal allocation profiles as mentioned in Wang et al. (2014) and references within. Biogenic emission files were simulated using the Model of Emissions of Gases and Aerosols from Nature (MEGAN) version 2.1 (Guenther et al., 2012). Open burning emission files were generated by using the Fire Inventory from the National Center for Atmospheric Research (NCAR) (FINN) version 1.5 (Wiedinmyer et al., 2011). Dust and sea salt emission files were generated in-line, and the dust emission module was updated to be compatible with the 20-category Moderate Resolution Imaging Spectroradiometer (MODIS) land use data (Hu et al., 2016). The re-gridded emissions of individual species were mapped to model species needed by the SAPRC photochemical mechanism (Carter, 2010) and the AERO6 aerosol module. As shown in Fig. S2, anthropogenic emissions are much higher inside the SCB than in its neighboring regions. Seasonally, $\mathrm{PM}_{2.5}, \mathrm{SO}_{2}$, and $\mathrm{NO}_{x}$ emissions are higher in winter than in summer, but $\mathrm{NH}_{3}$ emissions are generally similar between the two seasons.

\section{Model Validation}

Hourly observations of meteorological parameters and air pollutants were used to evaluate the model performance. The observations of wind speed (WS) and wind direction (WD) at $10 \mathrm{~m}$ above ground level (a.g.l.), ambient air temperature at $2 \mathrm{~m}$ a.g.l. (T2), and relative humidity (RH) were obtained from the National Climate Data Center (NCDC; ftp://ftp.ncdc.noaa.gov/pub/data/noaa/, last accessed on June 20,2018$)$. The meteorological data were available at 1,434 and 101 stations in the $36-\mathrm{km}$ and $12-\mathrm{km}$ domains, respectively (Fig. 1). $\mathrm{PM}_{2.5}$ and $\mathrm{O}_{3}$ measurements were derived from the Air Quality Data Distribution Platform of China (http://106.37.208.233:20035/, last accessed on July $13,2018)$, which provided data at 94 NAQs in the SCB (Fig. 1). Almost all the NAQs are located in the urban and suburban areas. Quality control measures were taken to remove possible problematic data points with observed hourly $\mathrm{O}_{3}$ and $\mathrm{PM}_{2.5}$ greater than $250 \mathrm{ppb}$ and $1500 \mu \mathrm{g} \mathrm{m}^{-3}$, respectively. The data points with a standard deviation of less than $5 \mathrm{ppb}$ for $\mathrm{O}_{3}$ and $5 \mu \mathrm{g} \mathrm{m}^{-3}$ for $\mathrm{PM}_{2.5}$ within 24 hours were also removed. To calculate 24-h $\mathrm{PM}_{2.5}$ for a given day in a city, citywide hourly $\mathrm{PM}_{2.5}$ data should be available for at least 20 hours (MEP, 2012a). To calculate 1-h and 8-h $\mathrm{O}_{3}$ for a given day in a city, citywide hourly values should be available for at least 14 hours between 08:00 and 24:00 (MEP, 2012b). If hourly $\mathrm{O}_{3}$ concentrations are available for $<14$ hours but the calculated 1-h $\mathrm{O}_{3}$ values are greater than the Chinese National Ambient Air 
Quality Standards (CNAAQS), the $1-\mathrm{h} \mathrm{O}_{3}$ values are still valid (MEP, 2012b).

\section{RESULTS AND DISCUSSION}

\section{Model Validation \\ Meteorology}

In order to assess the WRF model performance, the statistical metrics, including mean bias (MB), root mean square error (RMSE), and gross error (GE), were calculated based on the equations in Table S3 and then compared with the benchmarks suggested by Emery et al. (2001). When using the benchmarks to assess model performance, it should be noted that the benchmarks are considered as quantitative measures to compare with previous studies and model performance is affected by model parameterizations, landforms, meteorological reanalysis data, etc. As shown in Table S4, RH and T2 are both under-predicted (MBs < 0 ), and the under-predictions are greater in winter (MBs for RH and T2: -10.8 to $-6.5 \%$ and -0.9 to $-0.5 \mathrm{~K}$, respectively) than in summer (MBs for RH and T2: -2.9 to $-1.1 \%$ and -0.3 to $-0.1 \mathrm{~K}$, respectively). Compared to the benchmarks, the statistics of T2 are within the MB benchmark $(< \pm 0.5 \mathrm{~K})$ only in summer and there are no benchmarks for RH. In the two seasons, the MBs and RMSEs of WS (0.5-1.1 $\mathrm{m} \mathrm{s}^{-1}$ and 1.8-2.3) are slightly larger than the benchmarks $\left(< \pm 0.5 \mathrm{~m} \mathrm{~s}^{-1}\right.$ and $<2.0$, respectively), but the GEs of WS meet the benchmark value $\left(<2.0 \mathrm{~m} \mathrm{~s}^{-1}\right)$ in both seasons. The MBs of WD $\left(-5^{\circ}\right.$ to $\left.6^{\circ}\right)$ achieve the benchmark $\left(< \pm 10^{\circ}\right)$, but its GEs $\left(54-61^{\circ}\right)$ are larger than the benchmark $\left(<30^{\circ}\right)$. Overall, the WRF model performance is acceptable and comparable to previous studies in China (Hu et al., 2016; $\mathrm{Hu}$ et al., 2017a). The biases in the WRF simulations can be partially explained by the complex landforms in the 12$\mathrm{km}$ domain, which is located in the transition region from central China (mostly $<1000 \mathrm{~m}$ above sea level [a.s.l.]) to the QTP (> $3000 \mathrm{~m}$ a.s.l.) and the spatial resolution of the modeling.

\section{$P M_{2.5}$ and its Components}

Fig. 2 shows the time series of simulated and observed 24-h $\mathrm{PM}_{2.5}$ in the urban centers of the 18 cities (i.e., the center of the NAQs in the urban area of a city) and Table S5 shows relevant evaluation statistics, including normalized mean biases (NMBs), normalized mean errors (NMEs), fractional biases (FBs), and fractional errors (FEs). In general, both the simulated and observed 24-h $\mathrm{PM}_{2.5}$ are much higher in winter than in summer in the urban centers, and the simulations capture the peaks of 24-h $\mathrm{PM}_{2.5}$ most of the time (Fig. 2). The NMBs of $\mathrm{PM}_{2.5}$ meet the criteria $(< \pm 30 \%$; Emery et al., 2017) in all the urban centers in both seasons, except for that of Guanyuan (41\%), Mianyang (37\%), Meishan (31\%), Ziyang (48\%), and Chongqing (42\%) in winter and the NMB of Dazhou $(-39 \%)$ in summer (Table S4). The 24-h $\mathrm{PM}_{2.5}$ simulations meet the goals of NME $(<35 \%), \mathrm{FB}(< \pm 30 \%)$, and FE $(<50 \%)$ in all the cities in both seasons, except for the NME of Ziyang $(58 \%)$ in winter (Table S4). The possible causes leading to the uncertainties in $\mathrm{PM}_{2.5}$ simulations include but are not limited to the bias in the emission inventories, uncertainties in the meteorological modeling, complex landforms, and spatial resolutions of the modeling. However, the time series in Fig. 2 and the statistics in Table S5 give confidence in the predictions of 24-h $\mathrm{PM}_{2.5}$ in both seasons for the SCB.

The model performance on $\mathrm{PM}_{2.5}$ components (including sulfate, nitrate, and ammonia ions $\left(\mathrm{SO}_{4}{ }^{2-}, \mathrm{NO}_{3}{ }^{-}\right.$, and $\mathrm{NH}_{4}{ }^{+}$, respectively), $\mathrm{OC}$; $\mathrm{EC}$; and others) is assessed for the urban centers of Chengdu and Chongqing (Fig. 3), as observations are available from literature for the 2 cities. In Chengdu, the two largest contributors to $\mathrm{PM}_{2.5}$ are simulated to be secondary inorganic aerosols (SIA; including $\mathrm{SO}_{4}{ }^{2-}$, $\mathrm{NO}_{3}^{-}$, and $\mathrm{NH}_{4}^{+}$here; $40 \%$ in total) and $\mathrm{OC}(28-34 \%)$, while the simulated EC fractions are $\sim 5 \%$ in both seasons. These simulations are similar to the observations from Chen et al. (2016), which reported that SIA, OC, and EC accounted for $45 \%, 23-30 \%$, and $5 \%$ of $\mathrm{PM}_{2.5}$ from 2012 to 2013, respectively. Within SIA, the simulated contributions from $\mathrm{SO}_{4}{ }^{2-}, \mathrm{NO}_{3}{ }^{-}$, and $\mathrm{NH}_{4}^{+}$to $\mathrm{PM}_{2.5}$ are $21 \% / 30 \%$, $12 \% / 2 \%$, and $10 \% / 8 \%$ in Chengdu in winter/summer, and these values also agree with the observations of $20 \% / 25 \%$, $15 \% / 8 \%$, and $\sim 10 \%$ (Chen et al., 2016), respectively. Shi et al. (2017) reported $\mathrm{SO}_{4}{ }^{2-}, \mathrm{NO}_{3}{ }^{-}, \mathrm{OC}$, and $\mathrm{EC}$ contributions $(25 \%, 8 \%, 13 \%$, and $7 \%$ in winter and $23 \%, 4 \%, 12 \%$, and $9 \%$ in summer, respectively) similar to our simulations. In Chongqing, SIA and OC are also simulated to be the largest contributors to $\mathrm{PM}_{2.5}$. The simulated SIA fractions in Chongqing $35 \%$ and $30 \%$ in winter and summer, respectively) are lower than the observations $(45 \%$ and $50 \%$ in winter and summer, respectively) from Chen et al. (2017) but are higher than the annual mean fraction of $29 \%$ reported by Yang et al. (2011). The simulated OC fractions in Chongqing (38\% and 33\% in winter and summer, respectively) are higher than the observations (33\% and $25 \%$ in winter and summer, respectively) from Chen et al. (2017) and are close to the annual mean of 33\% reported by Yang et al. (2011). The EC fractions in Chongqing are similar between simulations $(\sim 12 \%)$ and observations $(\sim 10 \%$; Chen et al., 2012) in the two seasons. The discrepancies between the simulations and observations on $\mathrm{PM}_{2.5}$ components might be associated with the following: (1) The periods of observations and simulations are different; (2) emission inventories, meteorological modeling, etc. lead to the uncertainties of simulations on $\mathrm{PM}_{2.5}$ components; (3) locations of $\mathrm{PM}_{2.5}$ component measurements are not in the urban centers; and (4) concentrations of $\mathrm{PM}_{2.5}$ components may vary greatly within a urban center or a modeling grid cell $(12 \mathrm{~km} \times 12 \mathrm{~km})$.

\section{1-h and 8-h $\mathrm{O}_{3}$}

The time series of $8-\mathrm{h} \mathrm{O}_{3}$ in the 18 urban centers are presented in Fig. 4, and the evaluation statistics of 8-h and $1-\mathrm{h}_{3}$ are presented in Tables $\mathrm{S} 6$ and S7, respectively. Only 1-h and 8-h $\mathrm{O}_{3}$ concentrations larger than $30 \mathrm{ppb}$ are used to calculate NMB and NME, as a cutoff of 30-60 ppb is suggested by the U.S. Environmental Protection Agency (U.S. EPA, 2005), Hu et al. (2016), and Emery et al. (2017). The 8-h $\mathrm{O}_{3}$ concentrations above $30 \mathrm{ppb}$ in summer 


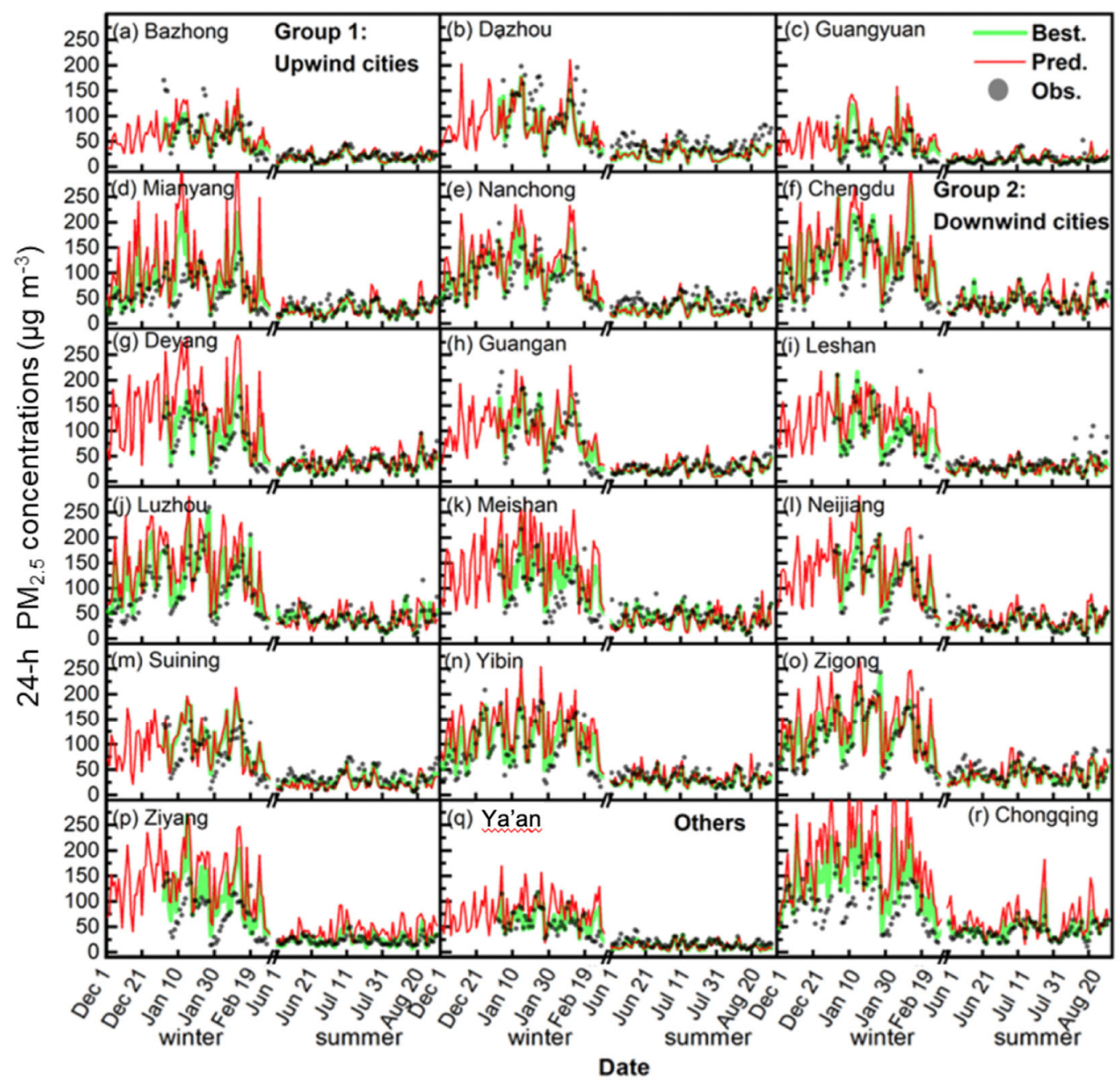

Fig. 2. Simulated and observed 24-h $\mathrm{PM}_{2.5}$ concentrations in the $18 \mathrm{SCB}$ urban centers in summer (June-August 2015) and winter (December 2014-February 2015). "Obs." shows observations. "Pred." indicates the simulations at the grid cells covering the urban centers, while "Best" indicates the simulated values closest to the observations within $3 \times 3$ grid cell regions that surround the urban center.

are mostly captured in the cities, except for Ya'an (Fig. 4). Also, the simulated diurnal patterns in summer well replicate the time and concentrations of $\mathrm{O}_{3}$ peaks in 11 cities in summer (Fig. S3). The NMBs and NMEs of 1-h and 8-h $\mathrm{O}_{3}$ for summer in all the 18 cities achieve the criteria $(\mathrm{NMB}< \pm 15 \%$ and NME $<25 \%$ ) recommended by Emery et al. (2017), except for the NMBs and NMEs of 1-h and 8-h $\mathrm{O}_{3}$ in Ya'an and the NMBs of $8-\mathrm{h} \mathrm{O}_{3}$ in Zigong and Suining (Tables S6 and S7). However, 1-h and 8-h $\mathrm{O}_{3}$ are both greatly over-predicted in winter, with $\mathrm{NMBs}$ and NMEs of $20-79 \%$, almost all of which do not meet the corresponding criteria ( $\pm 15 \%$ and $25 \%$, respectively). Thus, the model performance on 1-h and 8-h $\mathrm{O}_{3}$ is acceptable for summer, when the photochemical production of $\mathrm{O}_{3}$ due to anthropogenic emissions should be strongest in the basin.

\section{Spatial Variations: Air Pollutant Concentrations and Non-attainment Days}

$P M_{2.5}$ and its Components

Spatial distributions of $\mathrm{PM}_{2.5}, \mathrm{PM}_{2.5}$ components, and wind vectors are presented in Fig. 5 for winter and Fig. S4 for summer. The entire SCB experiences much higher $\mathrm{PM}_{2.5}$ concentrations in winter $\left(\sim 50-200 \mu \mathrm{g} \mathrm{m}^{-3}\right)$ than in summer $\left(\sim 5-60 \mu \mathrm{g} \mathrm{m}^{-3}\right)$. The higher $\mathrm{PM}_{2.5}$ concentrations in winter are partially due to the lower amount and frequency of precipitation and lower wind speed in the season according to observations (Ning et al., 2018; Zhao et al., 2018b). In general, $\mathrm{PM}_{2.5}$ concentrations are much lower in the rims of the SCB $\left(<75 \mu \mathrm{g} \mathrm{m}^{-3}\right.$ and $<20 \mu \mathrm{g} \mathrm{m}^{-3}$ in winter and summer, respectively) than in the inner SCB (100-200 $\mu \mathrm{g} \mathrm{m}^{-3}$ and 20-60 $\mathrm{g} \mathrm{g} \mathrm{m}^{-3}$ in winter and summer, respectively). Two hotspots of $\mathrm{PM}_{2.5}$ concentrations are found and they cover the urban centers of Chengdu and Chongqing and their adjacent regions in both seasons and have $\mathrm{PM}_{2.5}$ concentrations of $150-200 \mu \mathrm{g} \mathrm{m}{ }^{-3}$ in winter and $40-60 \mu \mathrm{g} \mathrm{m}^{-3}$ in summer. $\mathrm{SO}_{4}{ }^{2-}, \mathrm{NO}_{3}{ }^{-}, \mathrm{NH}_{4}{ }^{+}$, primary organic aerosol (POA), and EC present spatial variations similar to that of $\mathrm{PM}_{2.5}$ in both seasons. In contrast, no hotspots are found for SOA. In winter, SOA concentrations are also lower in the rims of the $\mathrm{SCB}\left(<4 \mu \mathrm{g} \mathrm{m}^{-3}\right)$ than in 
the inner areas (4-10 $\left.\mu \mathrm{g} \mathrm{m}^{-3}\right)$, except that the southwestern rim of the SCB also has higher values $\left(6-10 \mu \mathrm{g} \mathrm{m}^{-3}\right)$. In summer, higher SOA concentrations $\left(4-8 \mu \mathrm{g} \mathrm{m} \mathrm{m}^{-3}\right)$ are found in the inner and southwestern $\mathrm{SCB}$, as well as some regions in the north and east of the SCB. In summary, $\mathrm{PM}_{2.5}$ and most of its major components have concentrations

(a) Chengdu

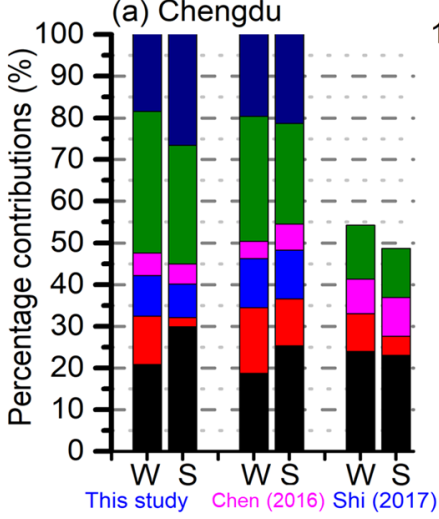

(b) Chongqing

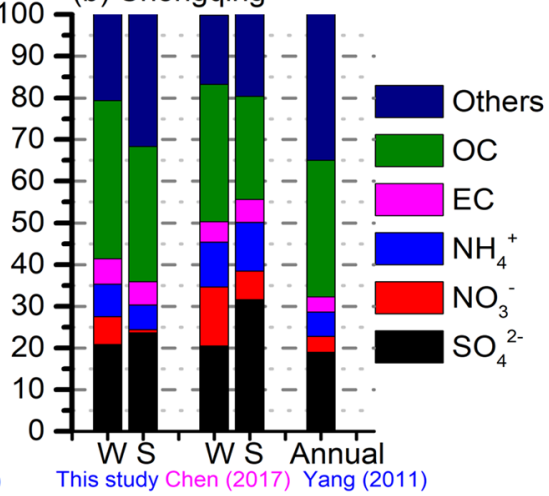

Fig. 3. Comparison of $\mathrm{PM}_{2.5}$ components in Chengdu and Chongqing between the observations and simulations. The simulations of this study are the averages in the winter (December 2014-February 2015) and in the summer (June-August 2015).

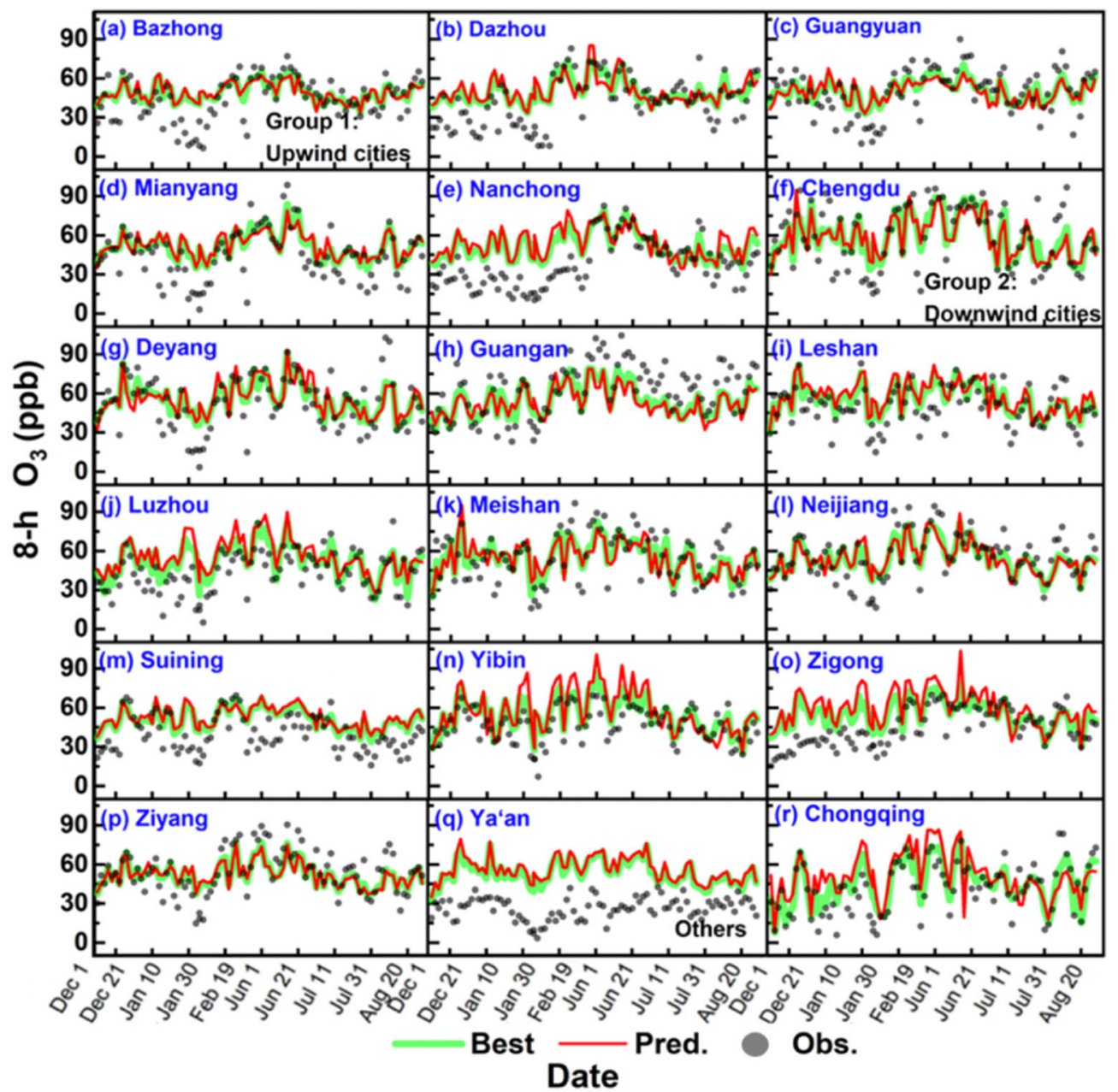

Fig. 4. Simulated and observed 8-h $\mathrm{O}_{3}$ concentrations in the $18 \mathrm{SCB}$ urban centers in summer (June-August 2015) and winter (December 2014-February 2015). "Obs." shows observations. "Pred." indicates the simulations at the grid cells covering the urban centers, while "Best" indicates the simulated values closest to the observations within $3 \times 3$ grid cell regions that surround the urban center. 

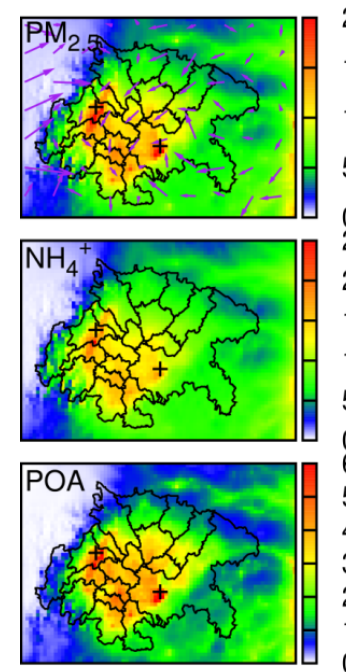

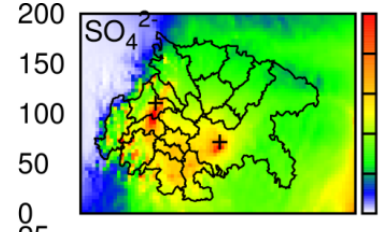

25
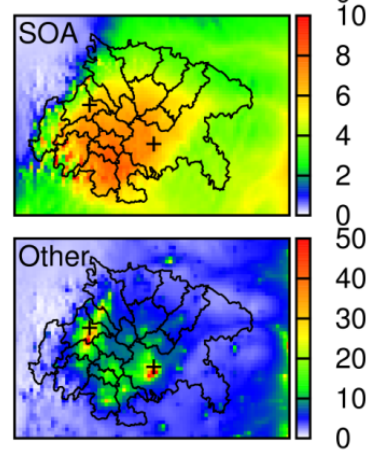

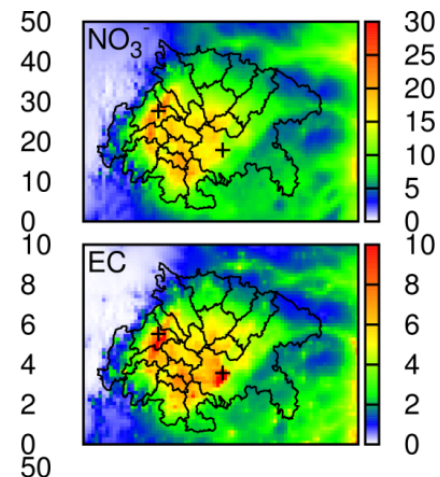

Fig. 5. Spatial variations of simulated wind vectors, $\mathrm{PM}_{2.5}\left(\mu \mathrm{g} \mathrm{m}^{-3}\right)$, and $\mathrm{PM}_{2.5}$ components $\left(\mu \mathrm{g} \mathrm{m}^{-3}\right)$ in winter (December 2014-February 2015) over the SCB. The left and right crosses show the urban centers of Chengdu and Chongqing, respectively.

increasing from the rims to the inner areas of the SCB, have two hotspots near the urban centers of Chengdu and Chongqing, and present decreasing gradients from the hotspots of Chengdu and Chongqing to their downwind areas. The above spatial variations may reflect not just the emissions and accumulation of air pollutants within the SCB but also the trans-boundary transport of air pollutants. In a companion paper, we have revealed that $25-52 \%$ and $39-66 \%$ of $\mathrm{PM}_{2.5}$ in each urban center are due to non-local emissions in summer and winter, respectively, and emissions outside the SCB can contribute up to $70 \%$ of $\mathrm{PM}_{2.5}$ in winter for the eastern SCB rims where $\mathrm{PM}_{2.5}$ concentrations are relatively low compared to that of other SCB regions (Qiao et al., 2019).

The percentage of non-attainment days (i.e., the days that do not meet the CNAAQS of $75 \mu \mathrm{g} \mathrm{m}^{-3}$ or the WHO guideline of $25 \mu \mathrm{g} \mathrm{m}^{-3}$ ) is shown in Fig. 6. In summer, only the $\mathrm{PM}_{2.5}$ hotspots located near the central cities of Chengdu and Chongqing have non-attainment days $>10 \%$ based on the CNAAQS. However, over half the area of the basin has $\mathrm{PM}_{2.5}$ exceeding the $\mathrm{WHO}$ guideline for $>20 \%$ of summer days, and $>80 \%$ of summer days near the $\mathrm{PM}_{2.5}$ hotspots do not meet the WHO guideline. In winter, over half the area of the basin has $\mathrm{PM}_{2.5}$ exceeding the CNAAQS for $>40 \%$ days and almost the entire basin has $\mathrm{PM}_{2.5}$ larger than the $\mathrm{WHO}$ guideline for $>70 \%$ of winter days. All of the above suggests that the entire basin has $\mathrm{PM}_{2.5}$ pollution based on the $\mathrm{WHO}$ guideline in winter.

\section{1-h and $8-h \mathrm{O}_{3}$}

Spatial variations of $\mathrm{O}_{3}$ concentrations and the percentages of non-attainment days in summer are presented in Fig. 7. 1-h and 8-h $\mathrm{O}_{3}$ concentrations are higher in the western and southwestern SCB and downwind from the urban center of Chongqing, with average concentrations of $65-80 \mathrm{ppb}$ and 55-70 ppb, respectively. Only in some of these higher$\mathrm{O}_{3}$ areas do 8-h and 1-h $\mathrm{O}_{3}$ exceed the corresponding
CNAAQS for $10-40 \%$ and $>5 \%$ of days in summer, respectively. However, almost the entire basin and over half of the basin have 8-h $\mathrm{O}_{3}$ concentrations larger than the WHO guideline ( $\sim 7 \mathrm{ppb})$ for $>40 \%$ and $>60 \%$ of summer days, respectively. Although the trans-boundary transport of $\mathrm{O}_{3}$ and its precursors has not been quantified yet, we have found that over $30 \%$ of the $\mathrm{O}_{3}$ concentration in the forested areas of the western SCB from 09:00 to 15:00 in August 2013 is associated with anthropogenic $\mathrm{NO}_{x}$ emissions (Qiao et al., 2019b), and this reflects the transport of $\mathrm{O}_{3}$ precursors from urban to rural areas.

\section{Comparison of the 18 Cities}

In both summer and winter, near-surface winds intrude on the SCB from the north, east, and southeast and then travel anti-clockwise within the basin (Figs. 5 and S4). Based on the wind vectors, we approximately categorized the 18 cities into 3 groups (Fig. 1), including upwind cities (Bazhong, Dazhou, Guangyuan, and Mianyang), downwind cities (Chengdu, Deyang, Guangan, Leshan, Luzhou, Meishan, Nanchong, Neijiang, Suining, Yibin, Zigong, and Ziyang), and others (Ya'an and Chongqing).

The citywide average concentrations and attainments of $\mathrm{PM}_{2.5}$ are compared among the 18 cities in Fig. 8. Citywide average $\mathrm{PM}_{2.5}$ concentrations are generally higher in the downwind cities $\left(106.5 \pm 13.6 \mathrm{\mu g} \mathrm{m}^{-3}\right.$ and $\left.24.3 \pm 4.9 \mu \mathrm{g} \mathrm{m}^{-3}\right)$ than in the upwind cities $\left(62.6 \pm 15.9 \mu \mathrm{g} \mathrm{m}^{-3}\right.$ and $15.6 \pm$ $\left.2.7 \mu \mathrm{g} \mathrm{m}^{-3}\right)$ and the other cities $\left(16.0 \pm 10.5 \mu \mathrm{g} \mathrm{m}^{-3}\right.$ and $66.0 \pm 28.9 \mu \mathrm{g} \mathrm{m}^{-3}$ ) in winter and summer, respectively. In summer, 24-h $\mathrm{PM}_{2.5}$ concentrations in the 18 cities exceed the CNAAQS for $<5 \%$ days but are higher than the WHO guideline for $12-55 \%$ days (except Ya'an). In winter, the percentages of non-attainment days are also much lower based on the CNAAQS (18-80\%) than based on the WHO guideline (65-100\%). Although $\mathrm{PM}_{2.5}$ concentration and its attainment both vary greatly among the cities, POA and $\mathrm{SO}_{4}{ }^{2-}$ are the largest contributors to $\mathrm{PM}_{2.5}$ in the 18 cities 

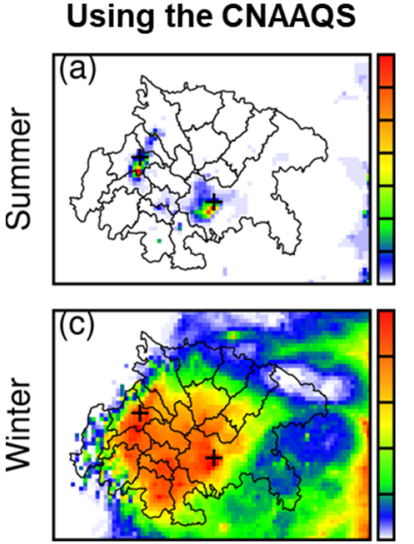

Using the WHO guideline

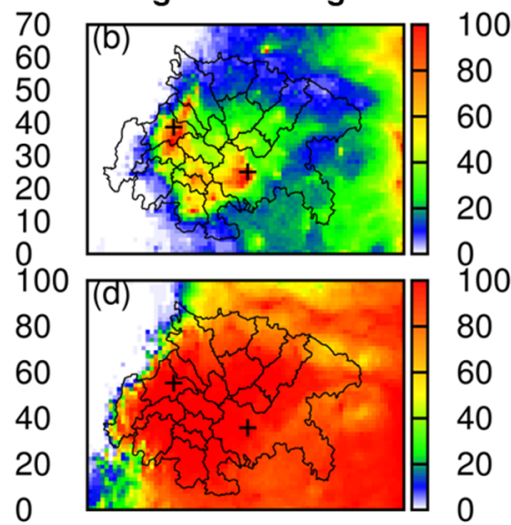

Fig. 6. The percentage of the days that do not meet the CNAAQS $\left(75 \mu \mathrm{g} \mathrm{m}^{-3}\right)$ and WHO guideline $\left(25 \mu \mathrm{g} \mathrm{m}^{-3}\right)$ for $24-\mathrm{h}$ $\mathrm{PM}_{2.5}$ concentrations in summer (June-August 2015) and winter (December 2014-February 2015). The black lines show the SCB city boundaries. The left and right crosses show the urban centers of Chengdu and Chongqing, respectively.

(a) 8- $\mathrm{h} \mathrm{O}_{3}$

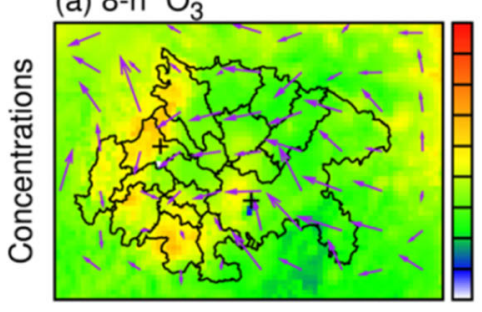

(c) 8-h $\mathrm{O}_{3}$ using the CNAAQS

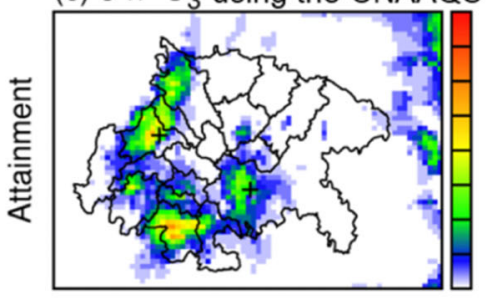

(b) $1-\mathrm{h} \mathrm{O}_{3}$

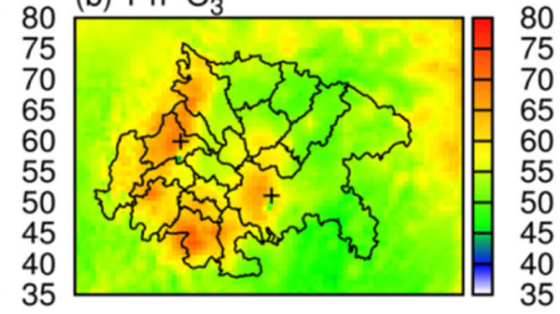

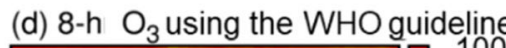

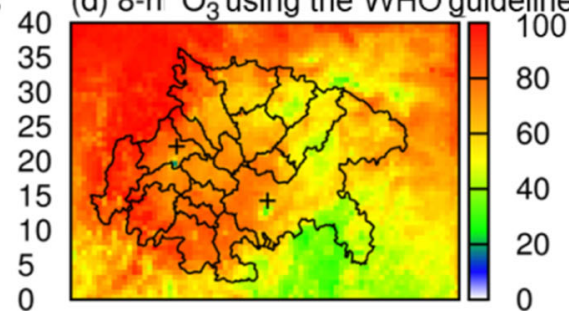

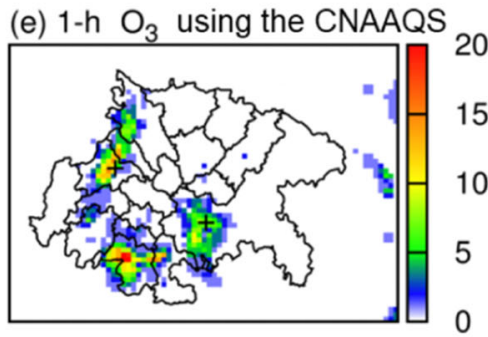

Fig. 7. (a) 8-h $\mathrm{O}_{3}$ concentrations and wind vectors, (b) 1-h $\mathrm{O}_{3}$ concentrations, (c-d) percentages of the days that do not meet the CNAAQS and WHO guideline for 8-h $\mathrm{O}_{3}$, and (e) percentage of the days that do not meet the CNAAQS for 1-h $\mathrm{O}_{3}$ in summer 2015. The concentrations and percentages are in $\mu \mathrm{g} \mathrm{m}^{-3}$ and \%, respectively. The black lines show the SCB city boundaries. The left and right crosses show the urban centers of Chengdu and Chongqing, respectively.

in winter, accounting for $26-35 \%$ and $19-30 \%$ of $\mathrm{PM}_{2.5}$, respectively (Fig. 9). In summer, $\mathrm{SO}_{4}^{2-}$ is still one of the most important contributors with contributions of $23-30 \%$ in the urban centers. Although the contributions from SOA $(20-33 \%)$ in summer are similar to or as important as that from POA (19-24\%) in the urban centers of Bazhong, Dazhou, Guangyuan, Leshan, Suining, Yibin, and Ya'an, these cities have average $\mathrm{PM}_{2.5}$ concentrations lower than 30 $\mu \mathrm{g} \mathrm{m}^{-3}$ in the season. In contrast to that of SOA, the contributions from $\mathrm{NO}_{3}{ }^{-}$decease from $6-15 \%$ in winter to $1-8 \%$ in the 18 cities in summer, as $\mathrm{NO}_{3}{ }^{-}$would be easily transformed into $\mathrm{NO}_{x}$ when the air temperature is over $30^{\circ} \mathrm{C}$ (Chen et al., 2003). Therefore, in order to reduce $\mathrm{PM}_{2.5}$ concentrations in the basin, we suggest that $\mathrm{POA}$ and $\mathrm{SO}_{4}{ }^{2-}$ should receive priority for being controlled in both seasons.

Citywide concentrations of 1-h and 8-h $\mathrm{O}_{3}$ are slightly higher in the downwind cities $(58.9 \pm 2.8 \mathrm{ppb}$ and $54.7 \pm$ $2.2 \mathrm{ppb})$ than in the upwind (53.5 $\pm 2.7 \mathrm{ppb}$ and $50.6 \pm 2.3$ $\mathrm{ppb})$ and other $(55.0 \pm 3.5 \mathrm{ppb}$ and $52.0 \pm 3.1 \mathrm{ppb})$ cities in summer, respectively (Fig. 8). 8-h $\mathrm{O}_{3}$ concentrations in the cities do not meet the WHO guideline for $54-88 \%$ of summer days and are higher than the CNAAQS for $0-12 \%$ of summer days. 1-h $\mathrm{O}_{3}$ does not meet the CNAAQS for $<5 \%$ of summer days in the 18 cities and there is no WHO guideline for 1- $\mathrm{h} \mathrm{O}_{3}$. As citywide 8-h $\mathrm{O}_{3}$ concentrations in the 18 cities exceed the WHO guideline for $50 \%$ of summer days, there is a need to develop relevant control measures for the basin.

\section{CONCLUSIONS}

In this study, the WRF/CMAQ modeling system was used to simulate the $\mathrm{PM}_{2.5}$ and $\mathrm{O}_{3}$ during winter and 


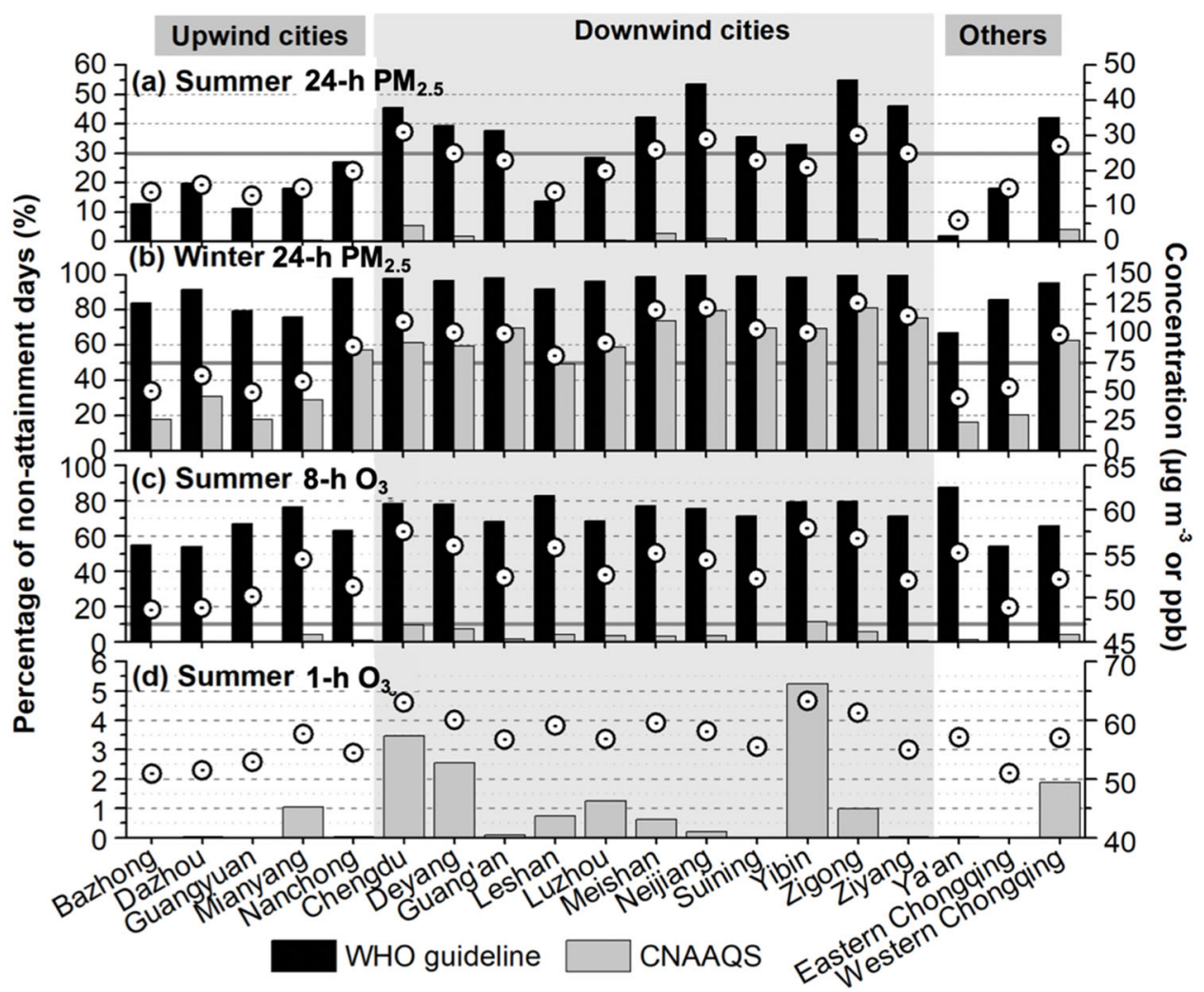

Fig. 8. The citywide average concentrations and non-attainment days of (a) summer 24-h $\mathrm{PM}_{2.5}$, (b) winter 24-h $\mathrm{PM}_{2.5}$, (c) summer 8-h $\mathrm{O}_{3}$, and (d) summer 1-h $\mathrm{O}_{3}$ in the $18 \mathrm{SCB}$ cities.

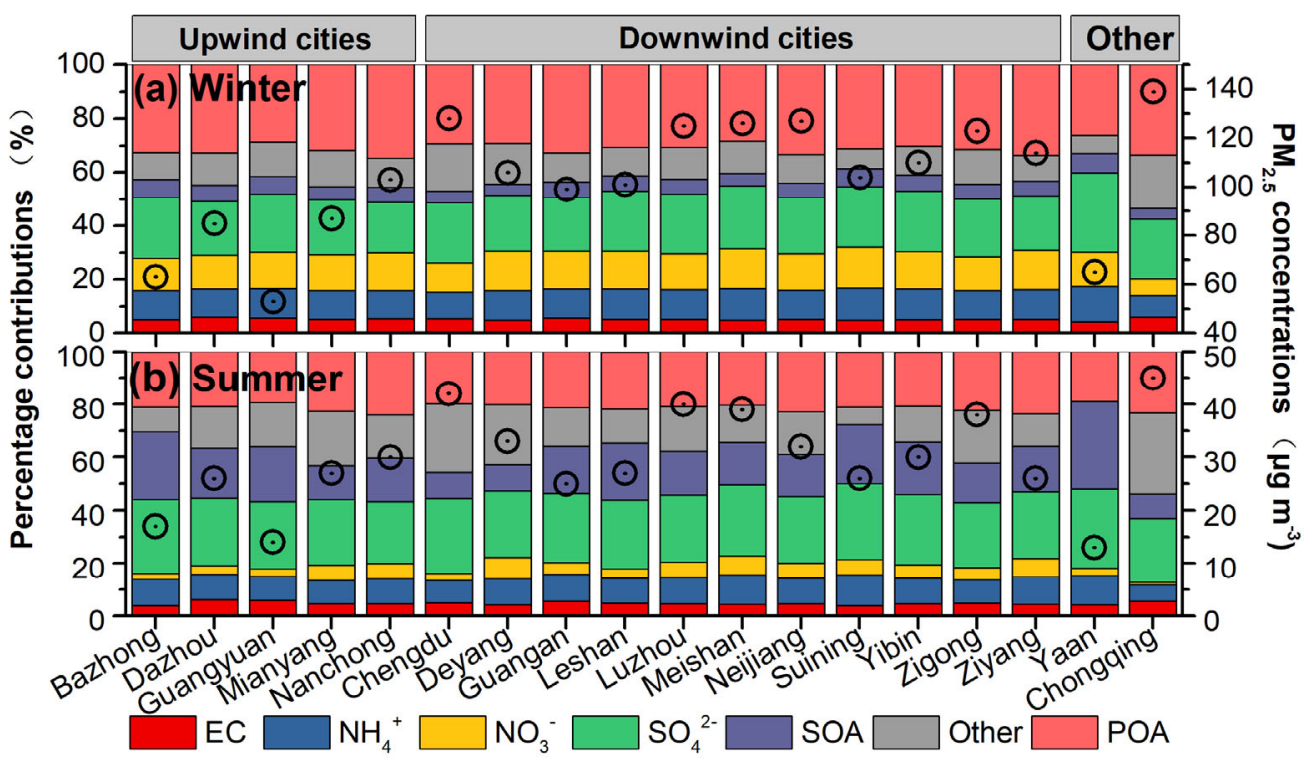

Fig. 9. Percentage contributions of different components to the total $\mathrm{PM}_{2.5}$ concentrations in the 18 SCB urban centers in summer (June-August 2015) and winter (December 2014-February 2015).

summer in the SCB, which contains the 2 largest cities in western China (namely, Chengdu and Chongqing). The $\mathrm{PM}_{2.5}$ increases in concentration from the rim of the basin (25-100 $\mu \mathrm{g} \mathrm{m}^{-3}$ and 5-20 $\mu \mathrm{g} \mathrm{m}^{-3}$ during winter and summer, respectively) to the inner areas (100-200 $\mu \mathrm{g} \mathrm{m}^{-3}$ and $20-60 \mu \mathrm{g} \mathrm{m}^{-3}$ during winter and summer, respectively) and exhibits 2 hotspots $\left(150-200 \mu \mathrm{g} \mathrm{m}^{-3}\right.$ and 40-60 $\mu \mathrm{g} \mathrm{m}^{-3}$ during winter and summer, respectively) near the urban centers of Chengdu and Chongqing. Decreasing gradients for the $\mathrm{PM}_{2.5}$ concentration are found in the regions downwind of these urban centers, reflecting the transport of air pollutants within the basin. POA and $\mathrm{SO}_{4}{ }^{2-}$ are the 
largest contributors to the $\mathrm{PM}_{2.5}$ during both winter and summer, with SOA being a third significant factor during the latter. Although noticeable hotspots are absent, the overall 1-h and 8-h $\mathrm{O}_{3}$ concentrations (55-70 ppb and 65$80 \mathrm{ppb}$, respectively) are higher in some rural and suburban areas, including those located on the western and southwestern rim of the SCB and in regions downwind of the urban center of Chongqing. In spite of the large spatial variations in the $\mathrm{PM}_{2.5}$ and $\mathrm{O}_{3}$ concentrations, the vast majority of the basin exceeds the WHO guidelines for 24-h $\mathrm{PM}_{2.5}$ and 8-h $\mathrm{O}_{3}$ on $>70 \%$ of winter days and $>40 \%$ of summer days, respectively. Although the basin landform favors the accumulation of air pollutants within the SCB, it inhibits the transportion of pollution from outside. Thus, strictly controlling emissions originating inside the basin may greatly reduce $\mathrm{PM}_{2.5}$ and $\mathrm{O}_{3}$ in this region.

\section{ACKNOWLEDGMENTS}

Portions of this research were conducted with highperformance computing resources provided by Louisiana State University (http://www.hpc.lsu.edu). This study is sponsored by the International Collaboration Project of the Science \& Technology Department of Sichuan Province (2017HH0048), the National Natural Science Foundation of China (41628102), the Program of Introducing Talents of Discipline to Universities (B08037), $\mathrm{PM}_{2.5}$ monitoring in the campuses of Sichuan University (SCU2015CC0001), and the Chinese Scholarship Council (201706245007).

\section{SUPPLEMENTARY MATERIAL}

Supplementary data associated with this article can be found in the online version at http://www.aaqr.org.

\section{REFERENCES}

Anger, A., Dessens, O., Xi, F., Barker, T. and Wu, R. (2016). China's air pollution reduction efforts may result in an increase in surface ozone levels in highly polluted areas. Ambio 45: 254-265.

Aunan, K., Ma, Q., Lund, M.T. and Wang, S. (2018). Population-weighted exposure to $\mathrm{PM}_{2.5}$ pollution in China: An integrated approach. Environ. Int. 120: 111120.

Byun, D. and Schere, K.L. (2006). Review of the governing equations, computational algorithms, and other components of the Models-3 Community Multiscale Air Quality (CMAQ) modeling system. Appl. Mech. Rev. 59: $51-77$.

Carter, W.P.L. (2010). Development of the SAPRC-07 chemical mechanism. Atmos. Environ. 44: 5324-5335.

Chen, L.W.A., Chow, J.C., Doddridge, B.G., Dickerson, R.R., Ryan, W.F. and Mueller, P.K. (2003). Analysis of a summertime $\mathrm{PM}_{2.5}$ and haze episode in the midatlantic region. J. Air Waste Manage. Assoc. 53: 946956.

Chen, Y., Xie, S. and Luo, B. (2016). Composition and pollution characteristics of fine particles in Chengdu during 2012 to 2013. Acta Sci. Circum. 1: 1021-1031.

Chen, Y., Xie, S., Luo, B. and Zhai, C. (2017). Particulate pollution in urban Chongqing of southwest China: Historical trends of variation, chemical characteristics and source apportionment. Sci. Total Environ. 584-585: 523-534.

Crippa, M., Guizzardi, D., Muntean, M., Schaaf, E., Dentener, F., van Aardenne, J.A., Monni, S., Doering, U., Olivier, J.G.J., Pagliari, V. and Janssens-Maenhout, G. (2018). Gridded emissions of air pollutants for the period 1970-2012 within EDGAR v4.3.2. Earth Syst. Sci. Data 10: 1987-2013.

Emery, C., Tai, E. and Yarwood, G. (2001). Enhanced meteorological modeling and performance evaluation for two Texas ozone episodes. https://www.tceq.texas.gov/ assets/public/implementation/air/am/contracts/reports/m $\mathrm{m} /$ EnhancedMetModelingAndPerformanceEvaluation. pdf. Accessed on July 12, 2018.

Emery, C., Liu, Z., Russell, A.G., Odman, M.T., Yarwood, G. and Kumar, N. (2017). Recommendations on statistics and benchmarks to assess photochemical model performance. J. Air Waste Manage. Assoc. 67: 582-598.

Fan, Q., Yu, W., Fan, S., Wang, X., Lan, J., Zou, D., Feng, Y. and Chan, P. (2014). Process analysis of a regional air pollution episode over Pearl River Delta Region, China, using the MM5-CMAQ model. J. Air Waste Manage. Assoc. 64: 406-418.

Guenther, A., Jiang, X., Heald, C., Sakulyanontvittaya, T., Duhl, T., Emmons, L. and Wang, X. (2012). The Model of Emissions of Gases and Aerosols from Nature version 2.1 (MEGAN2.1): An extended and updated framework for modeling biogenic emissions. Geosci Model Dev. 5: 1471-1492.

Hu, J., Chen, J., Ying, Q. and Zhang, H. (2016). One-year simulation of ozone and particulate matter in China using WRF/CMAQ modeling system. Atmos. Chem. Phys. 16: 10333-10350.

Hu, J., Huang, L., Chen, M., He, G. and Zhang, H. (2017a). Impacts of power generation on air quality in China-Part II: Future scenarios. Resour. Conserv. Recycl. 121: 115-127.

Hu, J., Wang, P., Ying, Q., Zhang, H., Chen, J., Ge, X., Li, X., Jiang, J., Wang, S. and Zhang, J. (2017b). Modeling biogenic and anthropogenic secondary organic aerosol in China. Atmos. Chem. Phys. 17: 77-92.

Kota, S.H., Guo, H., Myllyvirta, L., Hu, J., Sahu, S.K., Garaga, R., Ying, Q., Gao, A., Dahiya, S., Wang, Y. and Zhang, H. (2018). Year-long simulation of gaseous and particulate air pollutants in India. Atmos. Environ. 180: 244-255.

Lelieveld, J., Evans, J.S., Fnais, M., Giannadaki, D. and Pozzer, A. (2015). The contribution of outdoor air pollution sources to premature mortality on a global scale. Nature 525: 367-371.

Li, J., Cleveland, M., Ziemba, L.D., Griffin, R.J., Barsanti, K.C., Pankow, J.F. and Ying, Q. (2015). Modeling regional secondary organic aerosol using the Master Chemical Mechanism. Atmos. Environ. 102: 52-61.

Li, K., Liao, H., Zhu, J. and Moch, J.M. (2016). 
Implications of RCP emissions on future $\mathrm{PM}_{2.5}$ air quality and direct radiative forcing over China. $J$. Geophys. Res. 121: 12985-13008.

Li, K., Jacob, D.J., Liao, H., Shen, L., Zhang, Q. and Bates, K.H. (2019). Anthropogenic drivers of 20132017 trends in summer surface ozone in China. PNAS 116: 422-427.

Liao, J., Wang, T., Jiang, Z., Zhuang, B., Xie, M., Yin, C., Wang, X., Zhu, J., Fu, Y. and Zhang, Y. (2015). WRF/Chem modeling of the impacts of urban expansion on regional climate and air pollutants in Yangtze River Delta, China. Atmos. Environ. 106: 204-214.

Ma, Z., Xu, J., Quan, W., Zhang, Z., Lin, W. and Xu, X. (2016). Significant increase of surface ozone at a rural site, north of eastern China. Atmos. Chem. Phys 16: 3969-3977.

Ministry of Environmental Protection of China (MEP) (2012a). Ambient air quality standards. Ministry of Environmental Protection of the People's Republic of China. http://kjs.mee.gov.cn/hjbhbz/bzwb/dqhjbh/dqhjzl bz/201203/W020120410330232398521.pdf. Last Access: Jan. 10, 2019.

Ministry of Environmental Protection of China (MEP) (2012b). Technical regulation for ambient air quality assessment. http://kjs.mee.gov.cn/hjbhbz/bzwb/jcffbz/20 1309/W020131105548549111863.pdf. Last Access: 10 Jan. 2019.

Ministry of Environmental Protection of China (MEP) (2013). Twelfth five-year plan on air pollution prevention and control in key regions. http://www.mee.gov.cn/gkml /hbb/bwj/201212/W020121205566730379412.pdf. Last Access: 10 Jan. 2019.

Ning, G., Wang, S., Ma, M., Ni, C., Shang, Z., Wang, J. and $\mathrm{Li}$, J. (2018). Characteristics of air pollution in different zones of Sichuan Basin, China. Sci. Total Environ. 612: 975-984.

Qiao, X., Guo, H., Tang, Y., Wang, P., Deng, W., Zhao, X., Hu, J., Ying, Q. and Zhang, H. (2019a). Local and regional contributions to fine particulate matter in the 18 cities of Sichuan Basin, southwestern China. Atmos. Chem. Phys. 19: 5791-5803.

Qiao, X., Wang, P., Zhang, J., Zhang, H.L., Tang, Y., Hu, J.L. and Ying, Q. (2019b). Spatial-temporal variations and source contributions to forest ozone exposure in China. Sci. Total Environ. 674: 189-199.

Shen, L., Jacob, D.J., Liu, X., Huang, G.Y., Li, K., Liao, H. and Wang, T. (2019a). An evaluation of the ability of the Ozone Monitoring Instrument (OMI) to observe boundary layer ozone pollution across China: Application to 2005-2017 ozone trends. Atmos. Chem. Phys. 19: 6551-6560.

Shen, L., Jacob, D.J., Zhu, L., Zhang, Q., Zheng, B., Sulprizio, M.P., Li, K., Smedt, I.D., Abad, G.G., Cao, H., Fu, T.M. and Liao, H. (2019b). The 2005-2016 trends of formaldehyde columns over China observed by satellites: increasing anthropogenic emissions of volatile organic compounds and decreasing agricultural fire emissions. Geophys. Res. Lett. 46: 4468-4475.

Shi, G.L., Tian, Y.Z., Ma, T., Song, D.L., Zhou, L.D.,
Han, B., Feng, Y.C. and Russell, A.G. (2017). Size distribution, directional source contributions and pollution status of PM from Chengdu, China during a long-term sampling campaign. J. Environ. Sci. 56: 1-11.

Sun, L., Xue, L., Wang, T., Gao, J., Ding, A., Cooper, O.R., Lin, M., Xu, P., Wang, Z. and Wang, X. (2016). Significant increase of summertime ozone at Mount Tai in Central Eastern China. Atmos. Chem. Phys. 16: 10637-10650.

United States Environmental Protection Agency (U.S. EPA) (2005). Guidance on the use of models and other analyses in attainment demonstrations for the 8-hour ozone NAAQS. Environmental Protection Agency of the United State. https://www3.epa.gov/scram001/guida nce/guide/final-03-pm-rh-guidance.pdf. Last Access: 10 Jan. 2019.

University Corporation for Atmospheric Research (UCAR) (2017). User's guide for the advanced research WRF (ARW) Modeling System Version 3.9. University Cooperation for Atmospheric Research. http://www2.mmm. ucar.edu/wrf/users/docs/user_guide_V3.9/ARWUsersG uideV3.9.pdf, Last Access: 10 Jan. 2019.

Verstraeten, W.W., Neu, J.L., Williams, J.E., Bowman, K.W., Worden, J.R. and Boersma, K.F. (2015). Rapid increases in tropospheric ozone production and export from China. Nat. Geosci. 8: 690.

Wang, D., Hu, J., Xu, Y., Lv, D., Xie, X., Kleeman, M., Xing, J., Zhang, H. and Ying, Q. (2014). Source contributions to primary and secondary inorganic particulate matter during a severe wintertime $\mathrm{PM}_{2.5}$ pollution episode in Xi'an, China. Atmos. Environ. 97: 182-194.

Wang, L., Xu, J., Yang, J., Zhao, X., Wei, W., Cheng, D., Pan, X. and Su, J. (2012). Understanding haze pollution over the southern Hebei area of China using the CMAQ model. Atmos. Environ. 56: 69-79.

Wang, S. and Hao, J. (2012). Air quality management in China: Issues, challenges, and options. J. Environ. Sci. 24: 2-13.

Wang, T., Xue, L., Brimblecombe, P., Lam, Y.F., Li, L. and Zhang, L. (2017). Ozone pollution in China: A review of concentrations, meteorological influences, chemical precursors, and effects. Sci. Total Environ. 575: 1582-1596.

Wiedinmyer, C., Akagi, S., Yokelson, R., Emmons, L., AlSaadi, J., Orlando, J. and Soja, A. (2011). The Fire INventory from NCAR (FINN)-A high resolution global model to estimate the emissions from open burning. Geosci. Model Dev., 4: 625-641.

World Health Organization (WHO) (2006). WHO air quality guidelines for particulate matter, ozone, nitrogen dioxide and sulfur dioxide. World Health Organization. http://apps.who.int/iris/bitstream/handle/10665/69477/ WHO_SDE PHE_OEH 06.02_eng.pdf;jsessionid $=352$ B69CDA01F $8134 \overline{2}$ DA4D9AF00A75317? sequence $=1$. Last Access: 10 Jan. 2019.

Yang, F., Tan, J., Zhao, Q., Du, Z., He, K., Ma, Y., Duan, F. and Chen, G. (2011). Characteristics of $\mathrm{PM}_{2.5}$ speciation in representative megacities and across China. Atmos. 
Chem. Phys. 11: 5207-5219.

Ying, Q., Li, J. and Kota, S.H. (2015). Significant contributions of isoprene to summertime secondary organic aerosol in eastern United States. Environ. Sci. Technol. 49: 7834-7842.

Zhang, L., Guo, X., Zhao, T., Gong, S., Xu, X., Li, Y., Luo, L., Gui, K., Wang, H., Zheng, Y. and Yin, X. (2019). A modelling study of the terrain effects on haze pollution in the Sichuan Basin. Atmos. Environ. 196: 77-85.

Zhang, Q., He, K. and Huo, H. (2012a). Policy: Cleaning China's air. Nature 484: 161.

Zhang, X., Cappa, C.D., Jathar, S.H., McVay, R.C., Ensberg, J.J., Kleeman, M.J. and Seinfeld, J.H. (2014). Influence of vapor wall loss in laboratory chambers on yields of secondary organic aerosol. PNAS 111: 58025807.

Zhang, X.Y., Wang, Y.Q., Niu, T., Zhang, X.C., Gong, S.L., Zhang, Y.M and Sun, J.Y. (2012b). Atmospheric aerosol compositions in China: Spatial/temporal variability, chemical signature, regional haze distribution and comparisons with global aerosols. Atmos. Chem. Phys. 12: 779-799.

Zhao, S., Yu, Y., Qin, D., Yin, D., Dong, L. and He, J. (2018a). Analyses of regional pollution and transportation of $\mathrm{PM}_{2.5}$ and ozone in the city clusters of Sichuan Basin, China. Atmos. Pollut. Res. 2: 374-385.

Zhao, S., Yu, Y., Yin, D., Qin, D., He, J. and Dong, L. (2018b). Spatial patterns and temporal variations of six criteria air pollutants during 2015 to 2017 in the city clusters of Sichuan Basin, China. Sci. Total Environ. 624: 540-557.

Zhu, J. and Liao, H. (2016). Future ozone air quality and radiative forcing over China owing to future changes in emissions under the Representative Concentration Pathways (RCPs). J. Geophys. Res. 121: 1978-2001.

Received for review, May 6, 2019 Revised, July 30, 2019 Accepted, August 1, 2019 